\title{
The Comprehensive Approach: An Effective Tool in the Pursuit of National Security and Defense Interests?
}

\author{
Miroslav Kelemen, Pavel Nečas, Stanislav Križovský, \\ and Lucia Mesárošová *
}

The "Comprehensive Approach" represents a new methodology of planning and performing military operations. The selection of actions is subject to an evaluation of the cumulative effects to reach the desired final condition: an entity that represents an asymmetric opponent in peace and war. The control over the process of continuous entity changes has to be directed toward the goal by fulfilling partial aims and by the transition through a set of intermediate stages defined in the decision process. At the same time, we can use the methodological apparatus of general system theory to modify the SWOT analysis (Strengths, Weaknesses, Opportunities, and Threats); a holistic approach can also be used to evaluate an asymmetric opponent within a complex adaptive system.

\section{Entity Changes: An Asymmetric Opponent}

We understand an entity as a specific "formation of reality which we are able to learn about, predict, think about as having certain characteristics; we can describe it and it can be a subject of our debates." In order to apply the comprehensive approach methodology for a fictitious state person, an image of a potential asymmetric opponent could be an examined entity that operates as an adaptive system consisting of components, subsystems, and interrelations in the certain system vicinity.

\section{First Step: Processing of an Asymmetric Opponent Situation Model}

We will carry out the description of an entity structure for state and non-state actors in "state services" by working out an asymmetric opponent situation model of a state or non-state person) and identify its basic current characteristics in the following areas:

- $\quad$ Politics (P)

- Information technology (I)

- Warfare (W)

- Economics (E)

- $\quad$ Social conditions (S)

\footnotetext{
Brigadier General Miroslav Kelemen is an associate professor and Rector in the General M. R. Štefánik Armed Forces Academy in Liptovský Mikuláš, Slovakia. Colonel Pavel Nečas is an associate professor and Vice-Rector for Science in the General M. R. Štefánik Armed Forces Academy in Liptovský Mikuláš. Stanislav Križovský is head of the Personnel Security Institute, at the University of Security Management in Košice, Slovakia. Lucia Mesárošová teaches at the University of Security Management in Košice.

1 FILIT: Otvorená filozofická encyclopedia; available at www.fmph/uniba.sk/filit.
} 
- Religion $(\mathrm{N})$.

The introduced basic areas of the examined entity's structure normally respect the DIME model (Diplomacy, Information, Military, Economy), which is applied in order to engage in the complex evaluation of a given country's potential. They create the conditions for discovering the "body and soul" of an asymmetric opponent- that is, for evaluating the potential of the coordinated, current, and effective use of all the tools available to the state. The Comprehensive Approach represents operations designed and planned within a system in which the full range of direct, indirect, and cascade effects are deliberated; they will be achieved (with different levels of success) through the application of military, diplomatic, economic, and psychological tools. ${ }^{2}$ The basic parameters of an entity specified as "PIWESN" represent so-called "meta-language" which, as a rule, is created for characterizing an asymmetric opponent through a description of its system elements, subsystems, relations, and priorities among them (as in morphological analyses).

In particular areas, we primarily identify the weak points of the entity in its present condition, which we indicate within the range of SL 1 to SL 5. Second, we identify the strong points of the entity in its present condition, which we indicate within the range of Sl 1 to S1 5. What is the purpose of thus describing the entity's weak and strong points? The weak points can reveal the "Achilles' heel" of an opponent, and may indicate potential actions or targets that will help achieve continuous entity conditions on its trajectory towards the final target state. Identifying the strong points can tell us which areas to either avoid or defend ourselves from, while at the same time working to eliminate their influence on us and our operations. Aside from this, an analysis of strong and weak points can result in the generation of cases that can later be utilized for further study.

\section{Second Step: Analysis of an Asymmetric Opponent's Weak and Strong Points}

The evaluation of an asymmetric opponent's weak and strong points in particular areas expresses the certain effect as the present reality condition that is elicited, in causal relation, from a new condition, which is referred to as a "reason." The reason represents the condition or phenomenon that determines the formation of a new condition or an effect. In this step, primary attention is paid to identifying the most probable reasons for each weak and strong point of an entity, generally using casual analysis - that is, "the method of revealing of causal phenomena relations ... in sociology ... [in which] ... mathematical-statistical procedures, correlation indexes, factor analysis, discriminant analysis etc. are used." ${ }^{3}$ The possible reason for each point of an entity is indicated as follows: P SL 1 to P SL 5 or P SI -1 to P SI -5 . The causal relation expresses objective reality when the reason does not fall out, or it initiates a response in particular conditions. We have to take into account the different forms of relations: se-

2 Paul K. Davis, Effects-Based Operations (EBO): A Grand Challenge for the Analytical Community (Santa Monica, California: RAND Corporation, 2001), p. xiii.

3 FILIT: Otvorená filozofická encyklopédia, available at www.fmph/uniba.sk/filit. 
rious, secondary, outer, inner, functional, procedural, short-term, long-term, linear, non-linear, immediate, conveyed, logical, accidental, permanent, temporary, etc.

\section{Third Step: The Risk Appraisal}

After completing the "matrix" of an asymmetric opponent situation model, we will conduct a risk appraisal of the entity's identified weak and strong points. According to the specialists, the risk appraisal should not start from a threat analysis, but rather from a value analysis - that is, it should begin with an analysis of our defense interests (including their vulnerabilities) and countermeasures.

The risk is not judged from the threat potential posed by the entity's weak and strong points. It is instead primarily evaluated from the point of view of the threats to state security interests in a particular area. The Winkler equation of a risk ${ }^{4}$ is considered to be the most useful deterministic tool for quantitative risk evaluation, both on a numerical and word scale.

$$
\text { Risk }=\frac{\text { Motivation } \times \text { Threat potential } \times \text { Vulnerability } \times \text { Value }}{\text { Countermeasures }}
$$

As set forth in the equation above, the intelligence community understands that "the risk is defined as directly proportional to ordinal quantities of threat motivation as an active subject, to this subject's potential, the vulnerability of the endangered value, and the value as such, and indirectly proportional to an ordinal quantity of countermeasures, in principle, to reduce the value."

The risk evaluation of the entity's weak and strong points is indicated as R 1 to R6-i.e., it expresses nominal risk, very low risk, low risk, medium risk, high risk, and very high risk. The introduced evaluation presumes the existence of an evaluation criteria chart of risk security. The risk appraisal is generally influenced by priority and sequence determination or parallelism of appropriate actions, in compliance with the required cumulative effect to achieve the final condition of entity behavior (as a system). The system behavior represents the method of realizing the aims and reactions on internal and external stimuli that are present in the system envirnment (these stimuli may also directly, indirectly, positively, or negatively influence also us).

\section{Fourth Step: Final Condition Definition - An Asymmetric Opponent}

The specialists understand the definition of the entity's final condition as a target that serves as the starting point for the implementation of the Comprehensive Approach during the decision process - i.e., for effect determination, the consequent selection of actions, and identifying the means of their implementation. "The final condition is rep-

4 M. Púčik, Základná bezpečnostná a spravodajská terminológia (Bratislava: MO SR, 2006), 11.

5 Ibid. 
resented by a complex of required conditions (circumstances) which is necessary to establish in a structure of a complex adaptive system (a subject behaving as an enemy or whatever ineligible social phenomenon could be, for example, of our interest)." ${ }^{\prime 6}$

"The determination of the required final condition is the task of the political state administration, which is [responsible] for [the exercise] of all available tools of state power." "In the presented framework, the armed forces also include the state's defense and security interests. In the matrix of a situation model of an asymmetric opponent, the required final condition is qualitatively described through the identification of particular situations in which we want to place the opponent. The resolution of the differences between the final target condition and the present condition of an opponent's behavior is the solution of a social character complex problem with a large number of values and a set of entity conditions. From the reasons mentioned above, it is necessary to work precisely in teams of analysts and to fully utilize the available software support for the whole process of entity behavior changes.

\section{Fifth Step: The Entity Change - An Asymmetric Opponent}

By the word "change" we mean "the most generous form of entity existence which expresses each motion, influence, inner transformations, quantitative expansion and reduction of characteristics as well as qualitative entity transformation." ${ }^{\circ}$ We are typically able to carry out a successful change (partial or final) in three steps by:

- Discontinuance of present entity level

- Performance of entity change towards the new qualitative or quantitative entity condition

- Stabilizing of achieved (whether partial or final) condition of entity behavior.

We know from our own practice, as well as the practices of commercial and noncommercial companies, that most required changes are planned. But real life requires being able to solve accidental, immediate, unexpected, and operative changes. We have to be prepared for these situations, and in order to be so we must improve the personal abilities of our employees, enhance our fighting power and flexibility, and implement an organization that is specifically designed and tasked to manage the changes. One of the most effective tools in controlling both planned and operative changes involves the application of situation control methodology. Planned change is defined, according to specialists, by two main dimensions: "change phases which express conditions through which an organization has to go through when implementing changes and processes which respond to methods used for organization transfer from

${ }^{6}$ R. Žídek, Od stratégie ničenia $k$ stratégii kumulovaných účinkov na vôlu protivnika (Liptovský Mikuláš: ISŠ NAO, March 2005), 51.

7 R. Žídek and M. Kelemen, "Systémové vnímanie protivníka," Vojenské reflexie (Liptovský Mikuláš: NAO, 2006): 62.

8 FILIT: Otvorená filozofická encyclopedia. 
one condition to another." ${ }^{.9}$ In the case of the introduced definition, the application of planned changes in the security sector in order to address the behavior of an asymmetric opponent, we generally find the following steps.

Realizing the Need for an Entity Condition Change. Monitoring, analyzing, and evaluating the behavior of an opponent, which the state authority does through the use of available news on the national and international level, along with information from within the entity as well as its immediate vicinity.

Analytical-Synthetic Phase. In accordance with the system and holistic approach to the investigation of the entity, we carry out the modified SWOT analysis of an asymmetric opponent with an emphasis on the investigation of its present condition, the causality of its demonstration, and a risk evaluation from the point of view of the state security and defense interests in defined areas.

Vision Change Elaboration and Strategy Change Selection. An original vision of the state authority with analytical-synthetic information and knowledge is now developed and specified to address the required entity condition change; this involves the strategy selection directed toward achieving a required change in an asymmetric opponent (involving a change of target determination and all necessary processes, useful tools, and resources for change realization).

Performing the Change. This is only the right of the state authority that takes political responsibility for the consequences of the executed changes in the entity, similar to the change target determination, which represents the final condition of an entity and outlines the processes necessary for achieving the aim. The importance of responsibility is also highlighted by the knowledge that "the decision is made [under] conditions of certain limited threat which results from a lack of information about the future behavior of a decision-making subject and an inside decision object, more or less developed likelihood field, with higher or lower risk of its consequences, which creates certain tension between what exists, what we want to happen, and what will really happen." 10

Projecting Change. A determined central coordination committee and a project team that is controlled by an authority (supported by the highest levels within the state structure) having particular competencies in change execution will work out the results of the condition and process analyses of an asymmetric opponent in line with the vision and the decision of the state authority:

- Principles for the utilization of state resources in the process of bringing about a change

- Principles of effective and flexible control, monitoring, analysis, evaluation, and potential corrections of temporary change conditions and processes, co-

9 J. Borovský, Manažment zmien - cesta k rastu konkurencieschopnosti (Bratislava: Eurounion, 2005), 45.

10 Borovský, Manažment zmien, 53. 
ordination, cooperation, and communication of available tools in the change process

- Identification of temporary entity conditions (partial aims) in the process required to achieve change in the direction of the final state within a certain period of time

- Analysis of the possible impacts of the changes on expected processes in achieving temporary entity conditions

- Identification and analysis of the processes necessary to achieve temporary entity conditions and the defined final condition within a certain time frame

- Identification and analysis of the positive and negative forces for change execution on the national and international level inside and in the vicinity of an entity; projecting the future course of the asymmetric opponent under both present and prospective change conditions

- Estimation of the required resources to successfully achieve the change within a given time frame.

In the process of projecting change, it is important to define the temporary entity conditions that present the predictive task solution that is generally aligned with the model used. "The construction of a predictive model results from the knowledge that the models express the dependence of one quantity detected on a model object on the quantities of others." " The model thus represents the functional relation of the expected value of the dependent quantity on the independent entity quantities and on the parameterization of a selected model of entity analysis. There exist a huge number of utilizable algorithms that can be used to create predictive models of different types, but experts say that the most frequently used are the following: decision trees, neuron nets, and a regression statistical model (a model based on the nearest neighbors) and similar entities. The optimum solution for achieving the desired change in the behavior of an asymmetric opponent is an application of "a method of nearest neighbors (k-NN, where $\mathrm{k}=$ nearest neighbors) during the process of change projection." The model $\mathrm{k}-\mathrm{NN}$ predicts the unknown value of the dependent quantity on the basis of its resemblance to examples where this value is known. ${ }^{12}$ If we know the present and final entity condition, we use them to define the temporary conditions through which we will be most likely to accomplish a change. The specialists, working in the sphere of independent qualities, first define the distance function "d," which serves to provide a quantitative evaluation of the resemblance between two examples. On the basis of this function, they look for the predicted instance ("k") of the nearest neighbors (e. g., the known present condition and the required final entity condition) within a set of examples. The value of the dependent quantity is consequently determined on the basis of the so-called nuclear function. Experts regard the arithmetic average as the simplest nuclear function:

11 V. Mař́k, ed., Umélá inteligence 4 (Prague: Academia, 2003), 1:372, 374, 316.

12 B. V. Dasarathy, "NN Concepts and Techniques: Nearest Neighbours (NN) Norms," IEEE Computer Society Press (1991). 


$$
y(i)=1 / k \quad \sum_{j=1}^{k} y(j)
$$

The prediction for the " $\mathrm{i}$ " object (temporary entity condition) is then the average value of the dependent quantity at " $k$ " based on the nearest neighbors found in the examples, e.g., y (1) is the value of the objective function of the nearest neighbor, y (2) of the second-nearest neighbor, etc. The more complex nuclear function uses a distance function, which determines the importance of the y (j) value application. In the case of classificatory (not numerical) tasks - such as analyzing an asymmetric opponenta classificatory example, instead of an average value, is allocated to the concept that occurs most frequently in the vicinity of " $i$," the object of interest (i.e., among the nearest neighbors, or "k"). What is the possible application of the introduced method for our purposes? From the final condition of $\mathrm{St}_{\mathrm{n}}$ and the entity's present condition (asymmetric opponent $\mathrm{St}_{0}$ ), we first determine the temporary entity condition $\mathrm{St}_{2}$. Then we come to the step of defining other partial conditions: from the temporary condition $\mathrm{St}_{2}$ and present $\mathrm{St}_{\mathrm{o}}$ condition, we determine the temporary entity condition $\mathrm{St}_{1}$. Then, from the final condition $\mathrm{St}_{\mathrm{n}}$ and temporary condition $\mathrm{St}_{2}$, we define the temporary entity condition $\mathrm{St}_{3}$, etc. The total number of defined temporary entity conditions on the trajectory to the final condition of its behavior will depend on the decision of the state authority responsible. It represents a scale of expected qualitative entity changes - that is, it expresses the "susceptibility" of an entity, or the likelihood that it will change, in increments. On the other side of the ledger, real life will provide possible but unexpected entity condition changes that will react in a variety of ways - sometimes unpredictably, spontaneously, or unreasonably, and often excessively. From the introduced reason, we can derive a minimum set of entity conditions, composed of the change conditions we plan and expect, or a set created by all possible entity conditions in the process of a change (in the form of a decision tree or similar graphic representation).

Defining Effects. When we know the present entity behavior condition, and we have determined the temporary entity conditions on a trajectory to the final state, we can begin defining the effects for all entity transitions, from $\mathrm{St}_{\mathrm{o}}$ up to $\mathrm{St}_{\mathrm{n}}$.

The solution of a listed task can make the use of the entity-relation diagram easier, with an application of creating a concrete "multidimensional Entity-relation diagram" of an asymmetric opponent. ${ }^{13}$ This will help us to identify partial effects that can serve as steps on the path to the desired cumulative effect on the entity of interest.

A conceptual relation model of an entity identifies individual elements of real life "which should be depicted by a model (and then a database system) and mutual relations." The diagram creates:

13 A. Kurz, Data Warehousing: Enabling Technology (Bonn : MITP-Verlag, 1999). 
- The depiction of an entity type, using rectangles to represent a set of given type objects as an asymmetric opponent (a person, a group, etc.), of which all instances have the same attributes

- Attributes (depicted using ovals) that are attached to an entity of interest or correlation

- Entity-type relations (depicted using diamonds).

"In a process of asymmetric opponent behavior changes, we will use the creation of multidimensional diagrams for each analyzed area (parameter) of an asymmetric opponent in line with the modified SWOT entity analysis (a situation model)."14

Defining Actions and the Means for Their Achievement. On the basis of the predicted and required cumulative effects on the behavior of an asymmetric opponent, and in line with the allocated resources, we can begin to define the operations that will be undertaken against the entity. According to the specialists' opinions, we must bear in mind that one action can cause an effect in several areas, and that certain capabilities will be needed to achieve the desired effect, particularly if other operations will be required. "From the mentioned reason, it is necessary to make a list of mutual relations..." 15 This can lead to the development of an "effect-action," through the use of objective software developed for use in the Comprehensive Approach.

Change Realization. This step in particular relies on media support of and preparation for an entity condition change, on the national and international level.

Operations. The performance of actions on the basis of logical coordination, cooperation, and communication among all available resources and people involved, including partners and sympathizers. This normally includes a set of operations in the political, economic, military, and social realms, both within the entity and in its vicinity.

Monitoring, Analyzing, and Evaluating Operation Effects. In evaluating the achieved effects of the operation, we frequently complete a "decision tree" of all the anticipated conditions (as in the case of "morphological analysis"), ${ }^{16}$ or we conduct a simplified decision tree when classifying elements of effect evaluation in three groups:

1. Achievement of an expected (required) impact on the entity's behavior

2. A positive trend in the entity's condition without achievement of the required effect

3. A negative trend in the entity's condition characterized by deviation from the target effect on entity behavior.

14 Žídek and Kelemen, "Systémové vnímanie protivníka," 67.

15 R. Žídek, Od stratégie ničenia $k$ stratégii kumulovaných účinkov na vôlu protivníka (Liptovský Mikuláš: ISŠ NAO, March 2005), 68.

16 Guy Duczinski, "Effects-Based Operations: A Guide for Practitioners," presented to the $9^{\text {th }}$ International Command and Control Research and Technlogy Symposium (Copenhagen, 1416 September 2004); available at www.dodccrp.org/events/9th_ICCRTS/CD/papers/171.pdf. 
It is possible to perform the designed depiction of an achieved effect after each action/operation, or after a set of actions/operations. The diagram progresses from a tree root, which is characterized by the present condition $S_{o}$, compared to the final condition. In the case of a positive trend in the entity's condition where the final and temporary effects have not yet been achieved, we depict a leaf of the tree on the right of the root. After an additional action or a set of actions is carried out without a condition change, we depict a new leaf parallel with a tree trunk.

In the case of achieving a temporary entity condition, we add a leaf to a point that creates an intersection of the temporary entity condition (e.g., $\mathrm{S}_{1}$ ) and the tree trunk, or a so-called fork. If there is a negative trend in the entity's condition, featuring a deviation from the required effect and condition, we depict a leaf on the left of the root and continue the graphic depiction after an action or a set of actions, the same as in the positive case.

In achieving the desired final effect on the entity's behavior, we depict a tree trunk growing directly from a root. The simplified decision tree enables the fast and tabular graphic evaluation of the achieved effects after a set of performed actions, especially for the purposes of the political leaders or "high command" of a state.

\section{Sixth Step: Situation Control of a Change}

The approach to action/operation control (which, in principle, also creates an independent complex system) utilizing the methodology of situation control is mainly based on situation recognition and the estimation of the entity's actual condition. It uses the following situation classification to sort events into exemplary situation classes according to defined evaluation criteria which have control strategies predetermined in line with an action objective and required effect.

"A situation is a general concept of system condition (as used in automatic control theory) which expresses a decision process which prejudges development in context with existing condition." ${ }^{17}$ Under the notion of a complex system situation, "we understand the general condition of a complex system in relation to the environment."

The control strategy represents a set of alternatives that is the result of decision processes. The result of a control process depends on the selected strategy, influence of outer conditions on a system (e.g., an asymmetric opponent), the entity's internal condition, a decision maker (or a team of decision makers), and the influence of undetermined factors (e.g., unpredictable circumstances, otherwise known as the real world) in a given entity's surroundings. The process aim and and the selection of a set of evaluation criteria for the examination of an entity's condition is and will remain purely an area of human endeavor.

17 F. Vernadat, "An Artificial Intelligence Approach to Manufacturing Workshop Control Using a Situational Control Paradigm," in Applications of Artificial Intelligence in Engineering, ed. R. A. Adey (Cambridge: Springer, 1989), 1-17.

L. Madarász, Základné princípy situačného riadenia a formalizácie rozhodovacách procesov pri riadení zložitých hierarchických systémov (Košice: EF VŠT Košice, 1982). 
"Situation control is understood as control in real time," within which we derive the actual identified situation of the entity with respect to the required temporary or final condition, after addressing whatever divergences from the action/operation plans took place. That is, the ways of achieving the required cumulative effects on the entity are recalibrated based on information that is collected in order to enable us to intervene to correct the operation. The use of the situation control methodology enables us to seek the optimum solution in the shortest time possible after a divergence from the trajectory toward the final entity condition has been identified within the state security and defense apparatus. Achieving the required effects on an asymmetric opponent will rely on the effective use of human, material, technical, and financial resources, along with the deployment of military assets.

\section{Seventh Step: Improving the Achieved Final Entity Condition}

Modifying and improving the behavior of an asymmetric opponent can be accomplished through monitoring, analysis, and evaluation of the entity's condition. This effort will rely heavily on software support for the entire process of a change, which must be able to offer analysis of the multiple dimensions of the final entity condition.

\section{Eighth Step: Analysis of Change Control Experiences of an Identified Asym- metric Opponent}

The transfer and distribution of information regarding the experience of the operation to the relevant and authorized bodies within the vicinity of a given asymmetric opponent through the rubric of "a learning organization" is a valuable way to analyze the experience and capitalize on the lessons learned. It can also be an effective way to process recommendations to the state authority for future operations. Applied knowledge based on past experiences confirms the reality that "managing change in [a given] organization cannot be one-man show, but presents the tireless work of a manager's teams, [each of which is led] by natural leaders." 19

\section{Conclusions}

Combining a methodology of operations planning and implementation with an approach to operations, the Comprehensive Approach can help guide the formation and use of experienced expert teams of specialists for engagement with specific aspects of an entity of interest - in this case, an asymmetric opponent. The accurate work of these expert teams is determined by the team members' knowledge, experiences, and their ability to call on this store of past experience to predict future eventualities. The pursuit of effective control tools and software support to help effect change in an asymmetric opponent is a necessary part of the entire process. Achieving the required cumulative effect on the will and behavior of an adversary is possible only through coordinated and goal-oriented use of both state and non-state tools in defense of the state's security interests.

19 M. Kelemen, "Manažment zmien v procese budovania spôsobilostí OS SR," Vojenské reflexie (Liptovský Mikuláš: NAO, 2006): 49. 


\section{Bibliography}

Borovský, J.. Manažment zmien - cesta $k$ rastu konkurencieschopnosti. Bratislava: Eurounion, 2005.

Dasarathy, B. V.. NN Concepts and Techniques: Nearest Neighbours (NN) Norms. IEEE Computer Society Press, 1991.

Davis, Paul K.. Effects-Based Operations (EBO): A Grand Challenge for the Analytical Community. Santa Monica California: RAND Corporation, 2001.

Duczinski, Guy. Effects-Based Operations: A Guide for Practitioners In presented to the 9th International Command and Control Research and Technlogy Symposium. Copenhagen, 2004.

FILIT: Otvorená filozofická encyklopédia., 2010.

Kelemen, M.. "Manažment zmien v procese budovania spôsobilostí OS SR." In Vojenské reflexie, 49. Liptovský Mikuláš: NAO, 2006.

Kurz, A.. Data Warehousing: Enabling Technology. Bonn: MITP-Verlag, 1999.

Madarász, L.. Základné princípy situačného riadenia a formalizácie rozhodovacách procesov pri riadeni zložitých hierarchických systémov. Košice: EF VŠT Košice, 1982.

Marik, V.. Umělá inteligence. 4th ed. Prague: Academia, 2003.

Púčik, M.. Základná bezpečnostná a spravodajská terminológia. Bratislava: MO SR, 2006.

R. dek, Ží, and M. Kelemen. "Systémové vnímanie protivnika." In Vojenské reflexie, 62. Liptovský Mikuláš: NAO, 2006.

R. dek, Ží. Od stratégie ničenia $k$ stratégii kumulovaných účinkov na vôlu protivnika. Liptovský Mikuláš: ISŠ NAO, 2005.

Vernadat, F.. "An Artificial Intelligence Approach to Manufacturing Workshop Control Using a Situational Control Paradigm." In Applications of Artificial Intelligence in Engineering, 1-17. Cambridge: Springer, 1989. 